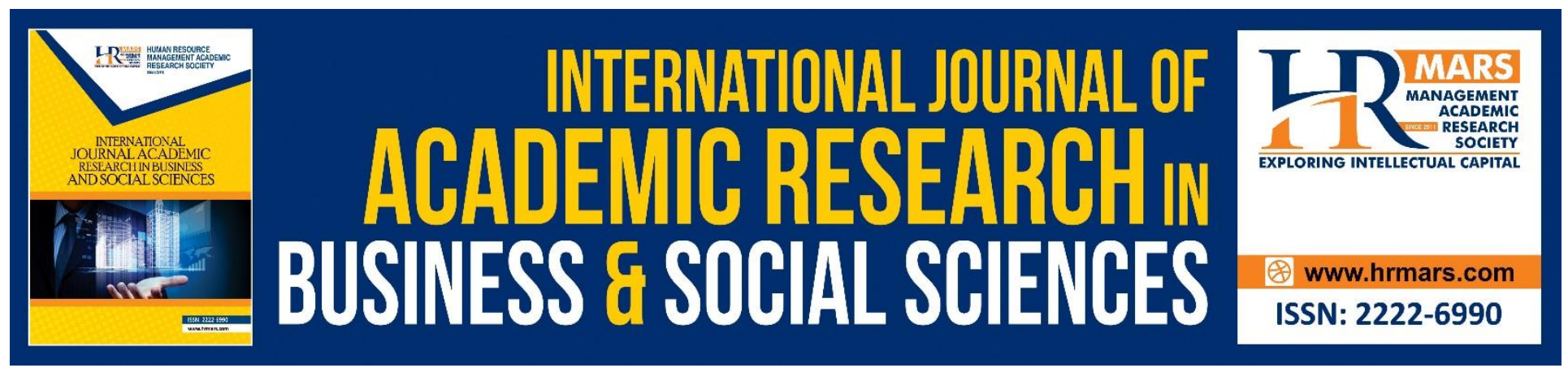

\title{
Preliminary Study of Augment Reality user Experience in Fashion Industry
}

Nor Farizah Mahmud, Mohamad Quzami An-Nuur Ahmad Radzi

To Link this Article: http://dx.doi.org/10.6007/IJARBSS/v10-i6/7466

DOI:10.6007/IJARBSS/v10-i6/7466

Received: 07 April 2020, Revised: 18 May 2020, Accepted: 04 June 2020

Published Online: 15 July 2020

In-Text Citation: (Mahmud, 2020)

To Cite this Article: Mahmud, N. F. M. Q. A.-N. A. R. (2020). Preliminary Study of Augment Reality user Experience in Fashion Industry. International Journal of Academic Research in Business and Social Sciences, 10(6), 991996.

Copyright: (c) 2020 The Author(s)

Published by Human Resource Management Academic Research Society (www.hrmars.com)

This article is published under the Creative Commons Attribution (CC BY 4.0) license. Anyone may reproduce, distribute, translate and create derivative works of this article (for both commercial and non-commercial purposes), subject to full attribution to the original publication and authors. The full terms of this license may be seen at: http://creativecommons.org/licences/by/4.0/legalcode

Vol. 10, No. 6, 2020, Pg. 991 - 996

http://hrmars.com/index.php/pages/detail/IJARBSS

JOURNAL HOMEPAGE

Full Terms \& Conditions of access and use can be found at http://hrmars.com/index.php/pages/detail/publication-ethics 


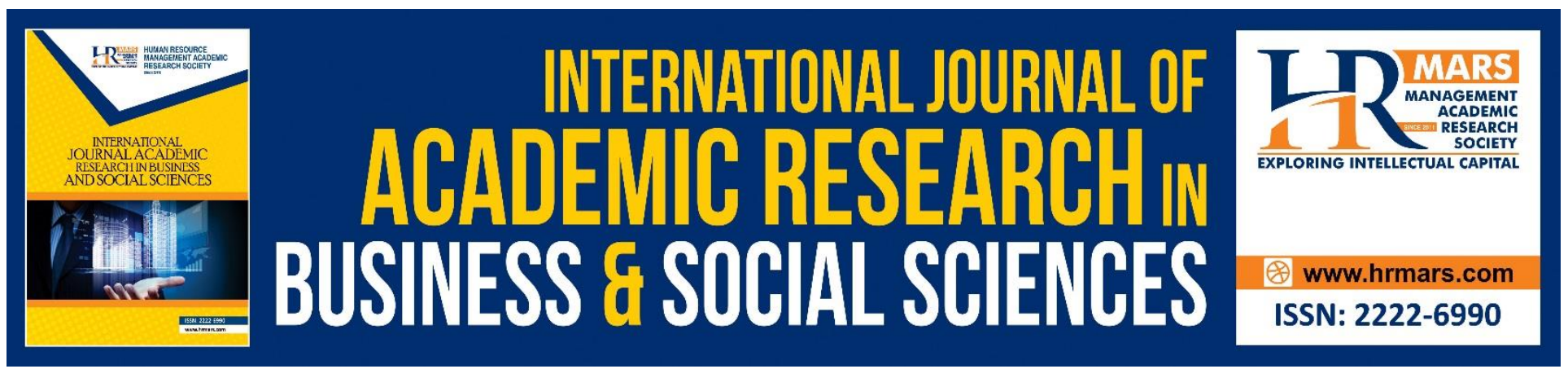

\title{
Preliminary Study of Augment Reality user Experience in Fashion Industry
}

\author{
Nor Farizah Mahmud \\ Faculty of Art and Design, Universiti Teknologi Mara, Shah Alam \\ Mohamad Quzami An-Nuur Ahmad Radzi \\ Faculty of Art and Design, Universiti Teknologi Mara, Perak Branch, Seri Iskandar, Perak
}

\begin{abstract}
This paper presents a study of augment reality user experience in fashion industry. Two main focus of this study are augment reality application and user experience. This study employs quantitative method. This method collects data from augment reality application experts and selected store customer. The documentation of existing augment reality and online store sample will support this study in order to achieve the aims of this research paper.
\end{abstract}

Keywords: Argument Reality, User Experience, Fashion Industry.

\section{Introduction}

Fashion is one of the industries that exist in this world. Bouvier (2018) informed that fashion is not only about clothing. He added, fashion also can be referred as human personal behaviour. This shown that fashion is not only about clothing but more than that. Besides, fashion had a long history of timeline. It might begin from the first cloth that had been made by mankind. Scholar also had used the cloth or any type of wear as a reference for them to identify the age or era of particular artwork. An example of postmodern era, fashion on that era can be referred based on their cloth characteristics. Basically, combination of aesthetic design and current popular culture on that time will become the main character (Morgado, 2014).

Today, Paris has known as a fashion city in this world. A lot of fashion shows and exhibitions had been done at Paris. Commercialization and globalization of fashion industry also had been started by this fashion city (Agency, 2019). Another well-known fashion city is London. They advocate London fashion week where every fashion fans gather together to celebrate the fashion week. Young fashion designer from local private university also took part in London Fashion week on 2017 (Laila, 2017). This shown the development of fashion industry in this world has become widely.

In local context, fashion industry also has given their impact here. It begins from the simple clothing industry to the huge fashion business. Malaysian education institution also contributed on developing and introduce more fashion market player inside Malaysia. For example, University Technology Mara (UiTM), Perak branch had organized Diploma Fashion Show for Diploma in Fashion students (Lah, 
2019). Besides grooming new fashion designer, this situation also create more demand to the fashion industry. Hence, more exhibition fashion show will be seen in future.

According to the press interview in 2019, Hugh Koh is one of the Malaysian fashion market players (Cheong, 2019). He said, fashion industry in Malaysia will become more globalization and digitalized. He added, customer will experience more digital experience when shopping in Malaysia fashion industry in future. Based from this press statement, fashion industry especially in Malaysia will face a new type of retail experience.

\section{Digitalization}

Digitalization in fashion industry context is one of the big markets to promote fashion industry widely (Wei \& Zhou, 2013). There are many online shopping portals exist today that sell the fashion goods to customers. In Malaysia, Zalora.com is a good example of fashion retail website. Many campaigns were created to maintain the good relationship with their customers (Lim, 2015). According to Lim (2015) too, Zalora also collaborated with a few local companies to engage more customers with their online store.

However, previous study stated that this digital online shopping phenomena has its own disadvantages. According Milong (2011), the digital online shopping was risky to the customer. Insecure payment, online shop cheating, cost and absence of sales person are examples of risks facing by online shopping customers (Muda \& Hassan, 2016). Hence, combination of physical store and online store might be a good choice for the market player to sustain their company and to stay relevant in the fashion industry.

\section{Augment Reality user Experience}

Augment reality is not something new in computer based technology. It has been introduced in 1992 (Li, Tsai \& Chen, 2015). Virtual reality and mixed reality are another terms that can be relate with augment reality (Bekele, 2018). Even though using quite similar technology, augment reality has its own benefit and core characters elements. Besides, Poushneh (2017) stated there are several user experience characteristic in augment reality. They are pragmatic quality, aesthetic quality, hedonic quality by stimulation and hedonic quality by identification.

\section{Problem of Statement}

Customer portray dissatisfaction when shopping in fashion retail store. This situation will make customers feel unhappy and uneasy when visiting or shopping at fashion retail stores. Previous study stated that satisfied customers will repeat their visit to the same store (Thomas, 2013). Hence, existing and future fashion retail stores should be looking forward to ensure their customers' loyalty to shop with them.

Other than that, technology has not been used widely in fashion industry. Even there are existing online shopping stores like Zalora, Lazada and Shoppe in Malaysia, the technology may not be fully utilized. According to Ng \& Ramasamy (2018), augment reality was the newest and innovative way for future retail scenario in Malaysia. They added, combination between online and offline store are highly needed to ensure the augment reality can be used widely especially those related to marketing industry. 
INTERNATIONAL JOURNAL OF ACADEMIC RESEARCH IN BUSINESS AND SOCIAL SCIENCES

Vol. 10, No. 6, June, 2020, E-ISSN: 2222-6990 @ 2020 HRMARS

\section{Methodology}

This research paper employs quantitative research method to fulfil the research objectives. There are four stages and phases of this research paper.

Table 1. Research Stages

\begin{tabular}{|l|l|}
\hline Stage & Process \\
\hline Stage 1 & $\begin{array}{l}\text { Collect primary data, existing augment reality application and online shopping } \\
\text { website }\end{array}$ \\
\hline Stage 2 & Identify good element of user experience on augment reality \\
\hline Stage 3 & Creating mobile application \\
\hline Stage 4 & Data collection using questionnaire and analysis \\
\hline
\end{tabular}

\section{Research Phases}

Phase 1

Data collection

The existing writing and study will be primary data for this research paper. Besides that, example of existing augment reality or related with will be collected in this phase. Publication, press report regarding augment reality and online shopping experience will also be recorded. This phase will become the base of this research paper.

\section{Phase 2}

Application development

An expert will clarify the best element on existing augment reality and online shopping website in this phase. They will be given a set of sample of augment reality and online shopping to be tested. Likert questionnaire will be given to an expert. The data will be recoded and extracted. In this phase, the recommended elements of user experience on augment reality and selected element on online shopping website will be identified. New mobile base application of augment reality will be develop. Researcher will choose the existing physical fashion stores (boutiques) in Malaysia with specific criteria to collaborate with this mobile base application.

\section{Phase 3}

Data collection/testing

The user experience questionnaire will be created in this phase. The questions will be based from an expert's questionnaire. Respondent that visited selected physical fashion store (boutique) will be given the questionnaire and test the augment reality mobile application when they are shopping in store. Accidental sampling method will be used to fulfil this phase.

\section{Phase 4}

Data analysis

Base from the data collection, researcher will compile and analyse the data. Suitable analysis software and selected theories will guide the researcher in this phase. 
INTERNATIONAL JOURNAL OF ACADEMIC RESEARCH IN BUSINESS AND SOCIAL SCIENCES Vol. 10, No. 6, June, 2020, E-ISSN: 2222-6990 @ 2020 HRMARS

\section{Significant of Study}

This research paper will contribute on new user experience when shopping. By completing this research paper, the good characteristic of user experience that can be used on augment reality application can be extracted. The new method of shopping which is using augment reality computer technology can be implemented on physical fashion retail store in the future. Researcher also believe that this research paper can be a guideline for further similar research in the future.

\section{Acknowledgement}

Firstly, I wish to thank God for giving me strength and good health to prepare this research paper. My gratitude and thank go to my past Masters supervisor and existing PhD supervisor. Thank you for the support and assist me. This research paper also could not be complete by support of my co-author and other who involved. Finally, that to my parents, thank you for their vision and guidance to educate me. Thank you.

\section{Corresponding Author}

Nor Farizah binti Mahmud

Faculty of Art and Design, Universiti Teknologi Mara, Shah Alam, Malaysia.

ceriza_ceria@yahoo.com

157, Lrg 6, Taman Sri Bahagia 2, Jln Sg. Manik, 36000 Teluk Intan, Perak Darul Ridzuan, Malaysia.

\section{References}

Agency. (2019). Paris Fashion Week highlights: Vibrant colours, extravagance and sustainability. Retrieved March 26, 2020, from https://www.thestar.com.my/lifestyle/style/2019/10/06/paris-fashion-week-springsummer-2020-highlights/

Bekele, M. K., Pierdicca, R., Frontoni, E., Malinverni, E. S., \& Gain, J. (2018). A survey of augmented, virtual, and mixed reality for cultural heritage. Journal on Computing and Cultural Heritage (JOCCH), 11(2), 1-36.

Bouvier, G. (2018). Clothing and meaning making: a multimodal approach to women's abayas. Visual Communication, 17(2), 187-207.

Cheong, B. (2019). Yearstarter2019: Malaysian fashion industry stays on trend. Retrieved March 25, 2020, from https://www.thestar.com.my/lifestyle/topics/2019/01/01/yearstarter2019malaysian-fashion-trend

Lah, F. C. (2019). Bertaraf antarabangsa. Retrieved March 26, 2020, from https://www.hmetro.com.my/bestari/2019/03/432337/bertaraf-antarabangsa

Laila, N. A. (2017). Pelajar LUCT sertai London Fashion Week. Retrieved March 26, 2020, from https://www.bharian.com.my/node/245860

Li, K. C., Tsai, C. W., Chen, C. T., Cheng, S. Y., \& Heh, J. S. (2015). The design of immersive English learning environment using augmented reality. In 2015 8th International Conference on UbiMedia Computing (UMEDIA) (pp. 174-179). IEEE.

Lim, R. (2015). Zalora is bringing back the 12.12 fever. Retrieved March 26, 2020, from https://www.thestar.com.my/metro/community/2015/11/24/bringing-back-the-1212fever-cyber-event-returns-to-engage-shoppers-across-region 
INTERNATIONAL JOURNAL OF ACADEMIC RESEARCH IN BUSINESS AND SOCIAL SCIENCES Vol. 10, No. 6, June, 2020, E-ISSN: 2222-6990 @ 2020 HRMARS

Milong, L. (2011). The analysis of strengths and weaknesses of online-shopping. In International Conference on Information and Management Engineering (pp. 457-464). Springer, Berlin, Heidelberg.

Morgado, M. A. (2014). Fashion phenomena and the post-postmodern condition: Enquiry and speculation. Fashion, Style \& Popular Culture, 1(3), 313-339.

Muda, M., Mohd, R., \& Hassan, S. (2016). Online purchase behavior of generation $Y$ in Malaysia. Procedia Economics and Finance, 37(16), 292-298.

$\mathrm{Ng}$, C. C., \& Ramasamy, C. (2018). Augmented Reality Marketing in Malaysia-Future Scenarios. Social Sciences, 7(11), 224.

Poushneh, A., \& Vasquez-Parraga, A. Z. (2017). Discernible impact of augmented reality on retail customer's experience, satisfaction and willingness to buy. Journal of Retailing and Consumer Services, 34, 229-234.

Thomas, S. (2013). Linking customer loyalty to customer satisfaction and store image: a structural model for retail stores. Decision, 40(1-2), 15-25.

Wei, Z., \& Zhou, L. (2013). E-Commerce Case Study of Fast Fashion Industry. In Intelligence Computation and Evolutionary Computation (pp. 261-270). Springer, Berlin, Heidelberg. 